\title{
Global change, Antarctic meteorite traps and the East Antarctic ice sheet
}

\author{
G. DELISLE \\ Bundesanstalt für Geowissenschaften und Rohstoffe (BGR), D-3000 Hannover 51, Germany
}

\begin{abstract}
Numerical models to assess the principal response of large ice caps to climatic changes are used as a guide to the interpretation of field evidence of changes in the glaciological regime in the coastal areas of Victoria Land and north Victoria Land, Antarctica. Based on the theoretical work, the following scenario is proposed: areas within about $300 \mathrm{~km}$ from the coast of Victoria Land experienced (i) significantly shallower ice slopes and a lesser degree of glaciation during most of the late Tertiary, (ii) steep slopes and thicker ice than today during glacial stages, and (iii) moderate thinning of the ice in intervening interglacial stages.

The model predicts, for central regions of Antarctica, a slightly thinner ice cap (lower snow-accumulation rate) during glacial stages, but an estimated $200 \mathrm{~m}$ thicker ice cap in warmer Tertiary climates than today. The calculated "Tertiary ice caps" indicate a probable tendency of periodic surges due to basal melting at the outer fringes.

Only modest changes of the ice thickness in reasonably good agreement with the model predictions for the current interglacial stage have been observed on four blueice fields, all located within $250 \mathrm{~km}$ of the coastline. Investigated ice fields include two meteorite traps - the Allan Hills Icefield and the Frontier Mountain meteorite fields. Antarctic meteorite traps are sustained by very specific glaciological conditions - in particular, only moderate changes in ice thickness over time. The sub-ice topography of these fields was determined by radar measurements and reveals a former, very different glaciological regime, which is interpreted as being associated with glacial processes, operative during the late Tertiary.

Field evidence for a hypsithermal event during the Holocene is presented.
\end{abstract}

\section{INTRODUGTION}

One important aspect of the ongoing global-change debate is the response of the East Antarctic ice budget to climatic changes. This paper presents field observations and results of radar surveys of the sub-ice topography of selected areas in Victoria Land and north Victoria Land, Antarctica, from which evidence for fluctuations of the ice level and different glacial regimes in the recent and more distant past will be derived. The probable causes of the observed changes will be identified on the basis of the results from numerical models investigating the response of large ice caps to climatic changes. For this purpose, an idealized model configuration - a flat-based, initially ice-free continent with a radius of $1750 \mathrm{~km}$ - was chosen. The numerical simulations with this model continent include the following stages:

Development of an ice cap to full size on an initially ice-free continent, assuming a warmer climate than today ("Tertiary climate").

Transition of the ice cap to a new configuration following a change from a "Tertiary" to a cold-stage climate.
Transition from a glacial stage to an interglacial stage climate.

All field surveys were carried out on and in the vicinity of various blue-ice fields, of which two are known for their high meteorite concentrations. The field work was done during the following expeditions:

The GANOVEX IV expedition (1984-85) by the Bundesanstalt für Geowissenschaften und Rohstoffe (BGR) to north Victoria Land, an expedition to the Allan Hills area in 1988-89. (logistically supported jointly by the U.S. National Science Foundation (U.S. NSF, U.S.A.), Max-Planck-Institut, Mainz, Germany, and BGR, Germany), the Italian expedition (1990-91) to north Victoria Land, the GANOVEX VI expedition (1990-91) by BGR to Victoria Land.

\section{PREVIOUS WORK}

A vast amount of literature on the glacial geology in the coastal areas of the East Antarctic continent has been summarized in Denton and Hughes (1981). A summary of aspects of the late Wisconsin and early Holocene glacial 
history of the Ross Embayment can be found in Denton and others (1991).

Glacial geologists have long suspected the East Antarctic continent of having been at least periodically covered in the past by more massive ice sheets. The evidence for this is the glacial striations on top of nunataks near the Polar Plateau, which rise up to $1000 \mathrm{~m}$ above the current ice level (see e.g. Denton and others, 1984; Höfle, 1987; Höfle and others, 1992). However, episodic rapid uplift during the Pliocene and/or Pleistocene (see e.g. Behrendt and Cooper, 1991) might offer an alternative interpretation. Additional evidence for temporarily thicker ice sheets comes from marine geologists, who have identified a number of major advances of Antarctic ice on to the Antarctic continental shelf (see e.g. Hinz and Block, 1983; Hinz and Kristoffersen, 1987; Bartek and others, 1991). Such events must be accompanied by a greater ice thickness in more central parts of Antarctica.

The discovery of glacially transported diatoms of late Pliocene age $2.2 \mathrm{~km}$ above sea level in the Transantarctic Mountains (Harwood, 1983, 1991) has been interpreted as evidence of periodically large-scale retreats and readvances of the ice sheet, during which the Wilkes Basin at least once became ice-free and was invaded by sea water. ${ }^{10} \mathrm{Be}$ dating of rock exposures from various nunataks in north Victoria Land indicates a regionally $1000 \mathrm{~m}$ higher ice stand sometime 2.7-4.0 Ma B.P. (Bremer and others, 1991). One is tempted to interpret these results as evidence of massive fluctuations of the East Antarctic ice sheet during the warmer Tertiary climate in comparison to the current interglacial stage. Substantial changes in sea level would result from such a scenario. Limited evidence to this effect is available from work of marine geophysicists (see e.g. Haq and others, 1987).

Little evidence for drastic changes in ice thickness on the Polar Plateau is available for the period of the latest glacial/interglacial cycles. Denton and others (1991) argued that the last advance of the Ross Ice Shelf during the Wisconsin was accompanied by little elevation change on the Plateau.

Various workers have attempted to simulate numerically the response of the Antarctic ice sheet to variations of sea level, climate and other parameters (see e.g. Oerlemans, 1982; Budd and others, 1984; Herterich, 1988; Huybrechts and Oerlemans, 1988). These models have demonstrated the major influence of the following two phenomena on ice-sheet growth or decay:

Sea-level fluctuations caused by glaciation/deglaciation in the Northern Hemisphere (Peltier and Tushingham, 1991) or other tectonic processes affect directly the behaviour of ice shelves and ice sheets. A drop in sea level allows ice shelves and ice sheets to advance further out on to continental shelf areas than at times of rising sea level.

The change of snow accumulation due to a climate change has an immediate effect on the thickness of ice sheets. As will be shown again below, the increased snow accumulation caused by the climatic warming since the last glacial stage has locally changed the ice thickness by several hundred metres.
Previously published models have concentrated either on the overall behaviour of the Antarctic ice sheet or on the ice shelves. The model presented below concentrates on the question of the specific reaction of the Antarctic ice sheet in near-coastal areas, that is, in places where meteorite traps are known to have existed for the past several hundred thousand years. A detailed discussion of all Antarctic meteorite collection sites has been given by Cassidy and others (1992).

\section{THE MODEL}

The intensity of glaciation of a continent reacting to climate changes is calculated in two dimensions. The response of the model ice sheet is driven by essentially three key factors:

Creep law for ice (Nye, 1959).

An accumulation function related to climate as shown in Figure 1a (more details in Delisle (1991)).

Past climate scenarios as derived from various studies on isotopes in Antarctic ice cores and deep-sea sediments (see e.g. Miller and others, 1987; Lorius and others, 1988).

The model calculates in iterative fashion ice flow and the temperature field in the ice body and the underlying bedrock. The set of equations used to calculate the growth of an ice sheet as a function of pre-defined climate changes has been given in Delisle (1991). To this has been added

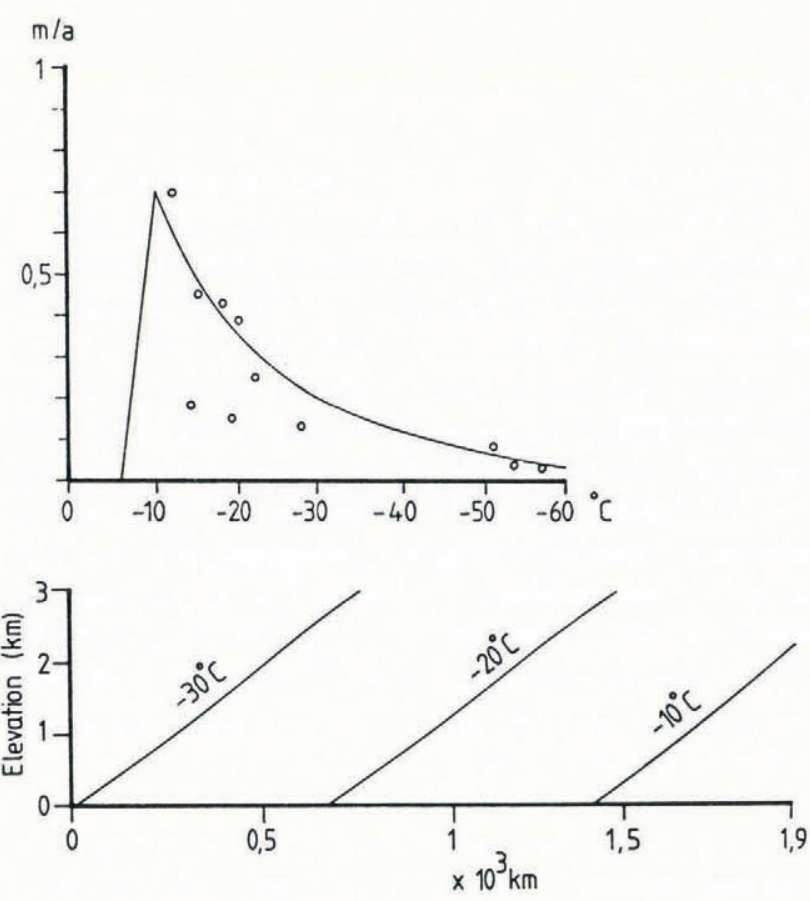

Fig. 1. Snow accumulation vs mean annual temperature used in the numerical model. Open circles give values measured at Antarctic stations (top). The mean annual air-temperature distribution (model I) is assumed over an initially ice-free continent at $t=0$ (bottom). 
the effects of frictional heat in ice (from Budd and Young, 1983) and a terrestrial heat-flow component of $60 \mathrm{~mW} \mathrm{~m}^{-2}$ at the ice base at $t=0$.

The model assumes, at $t=0$, an ice-free circular continent with a radius of $1750 \mathrm{~km}$. A mean annual temperature and an adiabatic gradient in air as shown in Figure $1 \mathrm{~b}$ is superimposed on its surface. The growing ice sheet will pass through a time period equivalent to climatic conditions, which we assume to have existed during the late Tertiary (warmer climate than today), followed by a Quaternary climate cycle (glacial and interglacial stage). The sequence of idealized climate changes as a function of time is shown in Figure 2. The air temperatures above the model ice sheet were adjusted accordingly during each climate change. The length of time for the idealized "Tertiary" and "Quaternary" periods was chosen to be sufficiently long to ensure that ice sheets $\mathrm{C}$ and $\mathrm{A}$ run into steady-state configurations. Four different models will be presented starting at $t=0$ with different initial conditions as summarized in Table 1. All models will end up with an ice-sheet configuration comparable to conditions observed in East Antarctica today.

The calculated changes of the ice profiles in response to the climatic settings as defined by A and B in Figure 2 are shown in Figure 3A-C. The results obtained for A, B and $\mathrm{C}$ are discussed below separately.

\section{Climatic setting A}

Case A gives ice-sheet configurations at the end of a prolonged cold period (glacial stage). The four models predict a range of $3.8-4.2 \mathrm{~km}$ in ice thickness at the centre point of the ice sheets. The ice-sheet configuration in peripheral areas is practically the same for all models considered. The low precipitation values during a glacial stage cause the ice cap to reduce its overall thickness, except along the periphery, in comparison with its configuration in warmer climates. The flanks steepen in response to the decreased plasticity of the ice and lower flow velocities.

\section{Climatic setting $\mathbf{B}$}

Case B gives ice-sheet configurations 10000 years after the beginning of an interglacial stage (equivalent to current climate) immediately following case A. Within this

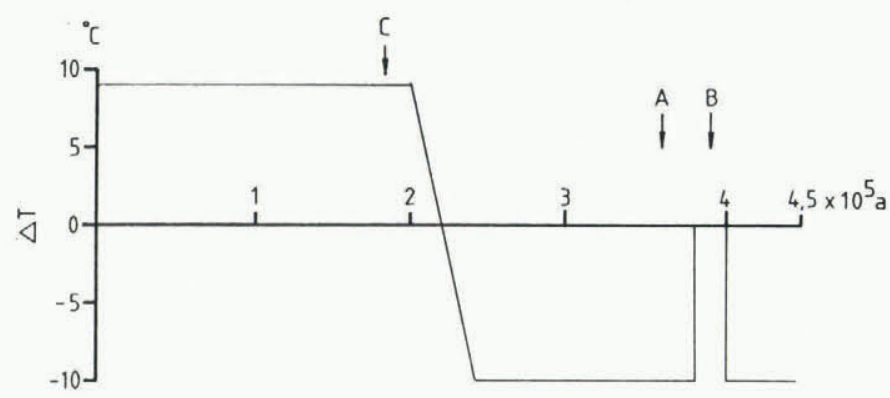

Fig. 2. Assumed variation of mean annual temperatures.

Shown is a fictitious course of climate change. Calculated ice sheets respond to the assumed climatic changes by taking up the new air temperatures on their surfaces and through the changing accumulation rates (see Fig. 1).
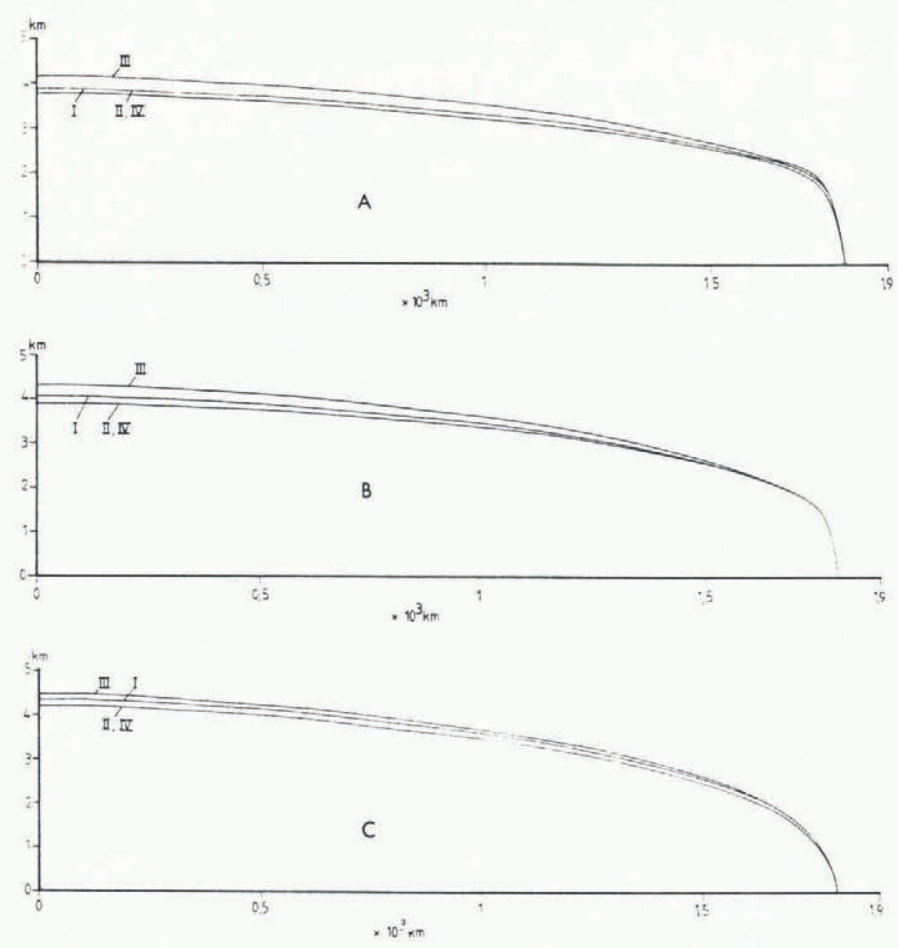

Fig. 3. Calculated ice-sheet profiles for a glacial stage (A), interglacial stage (B) and a "late Tertiary" climate (C).

period, the model ice cap has adapted to a large extent to the climatic warming in all four cases.

The calculations predict, in agreement with numerous models of other workers, for the transition from a glacial to an interglacial stage a moderate increase in ice thickness in central parts of the ice cap as a consequence of increased snow accumulation, and decreasing ice thickness in peripheral areas of the ice sheet. The difference between the ice-sheet configurations B and A for the four model cases considered is shown in Figure 4. The ice-thickness reduction in peripheral areas is due to two factors:

The increase in snow accumulation at the beginning of the interglacial stage rapidly displaces the cold ice at the front of the ice sheet.

Increasing ice temperatures cause increased rates of ice deformation, which translates into increased ice

Table 1

$$
T(x=0 ; t=0) \quad \text { Adiabatic } T \text {-gradient }
$$

$\begin{array}{lll}\text { I } & -30.0 & -4.0 \\ \text { II } & -20.0 & -7.0 \\ \text { III } & -20.0 & -5.5 \\ \text { IV } & -30.0 & -5.5\end{array}$




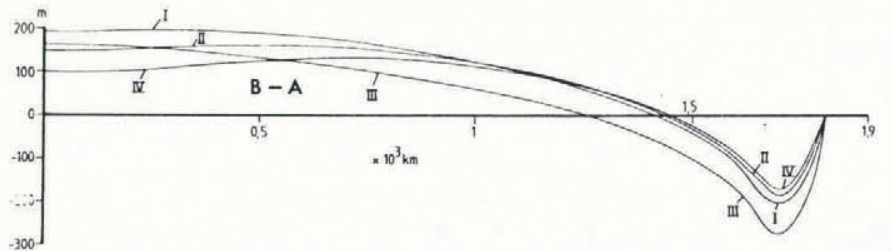

Fig. 4. Calculated differences in ice thickness between an interglacial and glacial stage. The ice thickness grows in the central part of the ice sheet and shrinks in near-coastal areas during an interglacial stage.

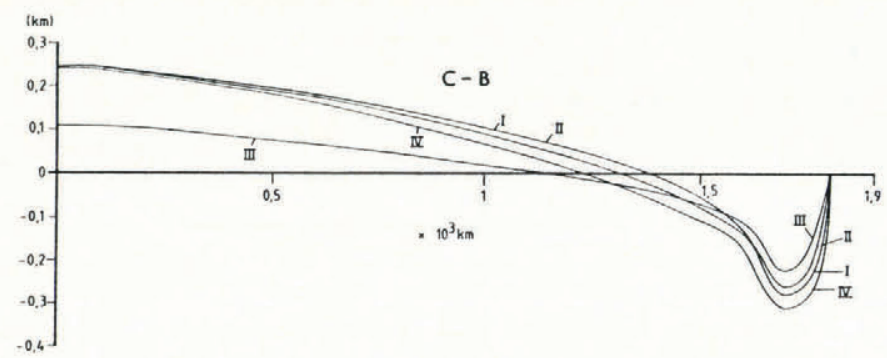

Fig. 5. Calculated differences in ice thickness between "interglacial stage" and "late Tertiary" ice sheets. The ice thickness grows in the central part of the ice sheet and substantially shrinks in near-coastal areas in a climate $8^{\circ} \mathrm{C}$ warmer than today.

velocities. The cold ice of the ice front, where the overall highest ice velocities occur, is therefore rapidly replaced.

The overall effect, according to our model, translates into regional thinning of the ice in the peripheral areas.

\section{Climatic setting $\mathbf{C}$}

Figure $3 c$ gives the ice-sheet configurations for a climate $8^{\circ} \mathrm{C}$ warmer than the present as it might have existed periodically during the late Tertiary (see e.g. Miller and others, 1987). The overall increased snow accumulation translates in all model cases into maximum ice-thickness values ranging between 4.2 and $4.5 \mathrm{~km}$ at the innermost point of the ice sheet. However, the surface slope at the periphery is much less than for case B (current climate). The difference between the ice-sheet profiles $\mathrm{C}$ and B is given in Figure 5. The calculated profiles for $\mathrm{C}$ have developed essentially within 30000-40000 years after initiation of the ice sheet on an initially ice-free continent.

The profiles represent the quasi-stationary ice-sheet configurations for the given climatic conditions, if one does not introduce appropriate equations to allow surging of the ice sheet.

For comparison, Figure 6 shows horizontal icevelocity components on the ice-sheet surface for cases $\mathrm{A}$, $\mathrm{B}$ and $\mathrm{C}$ at the zones where wet conditions at the base of the ice sheet are predicted by the model calculations (here the case of model III is shown). A "late Tertiary" ice sheet (C) differs from an "interglacial - or a glacial stage" ice sheet in two respects. A "late Tertiary" ice sheet

is wet-based in peripheral zones (roughly, the outer $600 \mathrm{~km}$ of the ice sheet). Such conditions occur under "interglacial/glacial stage" ice sheets only within a radius of $500-600 \mathrm{~km}$ from the centre point. The rate of transport of cold ice to basal regions is in the latter case insufficient to counteract basal melting induced by terrestrial heat flow, in particular, when the ice sheet has developed fully.

has ice velocities at the surface in excess of $100 \mathrm{~m} \mathrm{a}^{-1}$ within about $300 \mathrm{~km}$ from the ice front, which in reality should lead to periodic surge events. Comparable ice velocities are reached by an "interglacial stage" ice sheet only at an ice tongue and not at all by a "glacial stage" ice sheet.

Figure 7 shows the temperature distributions based on model III 500 and $1700 \mathrm{~km}$ from the centre point of the ice sheets for cases A, B and C. The coldest ice sheet (A) shows the least deformation of the temperature-depth profile by convective and advective ice transport. An almost linear increase of ice temperatures near the bottom is predicted except in near-coastal regions in case $\mathrm{C}$. The high amount of ice melting caused by high internal frictional forces near the ice base raises, in the latter case, the near-basal ice temperature to the melting point.

\section{FIELD OBSERVATIONS}

Field observations indicating past ice fluctuations within and at the western boundary of the Transantarctic Mountains are presented below. The localities of the sites visited are shown in Figure 8.

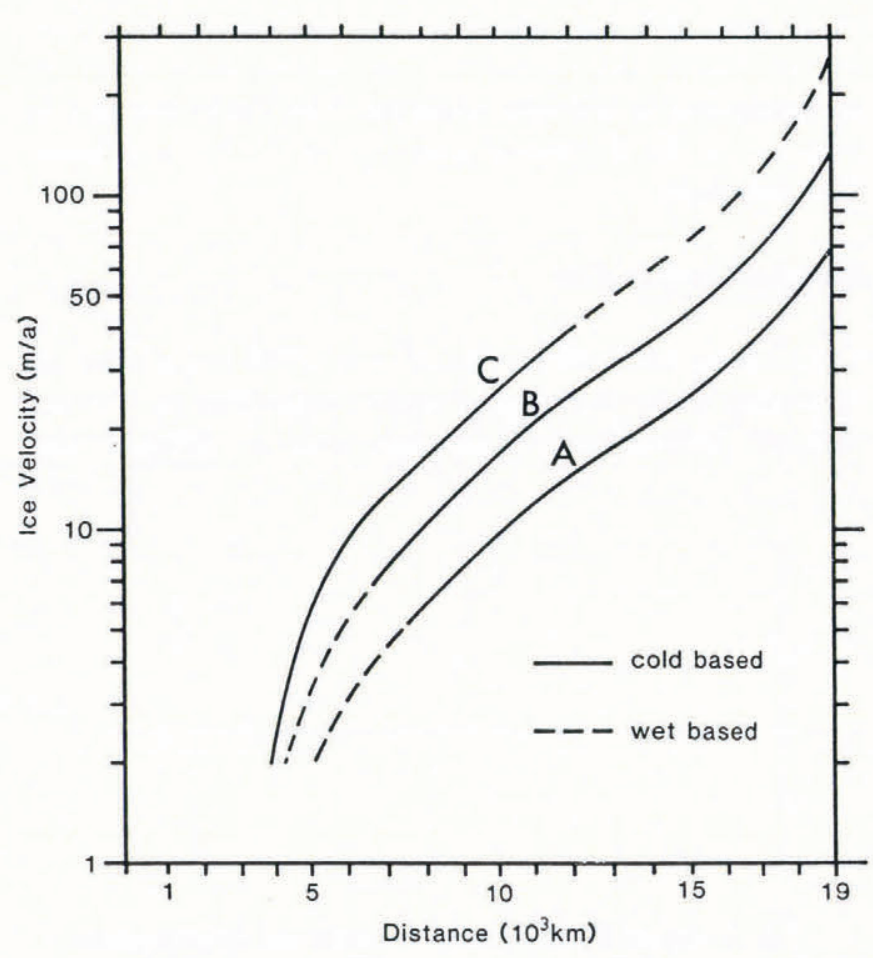

Fig. 6. Horizontal ice velocities at the ice-sheet surface (model III) in various climatic settings. Note the shift of the wet-based basal zone from the periphery to the centre as the climate deteriorates. 

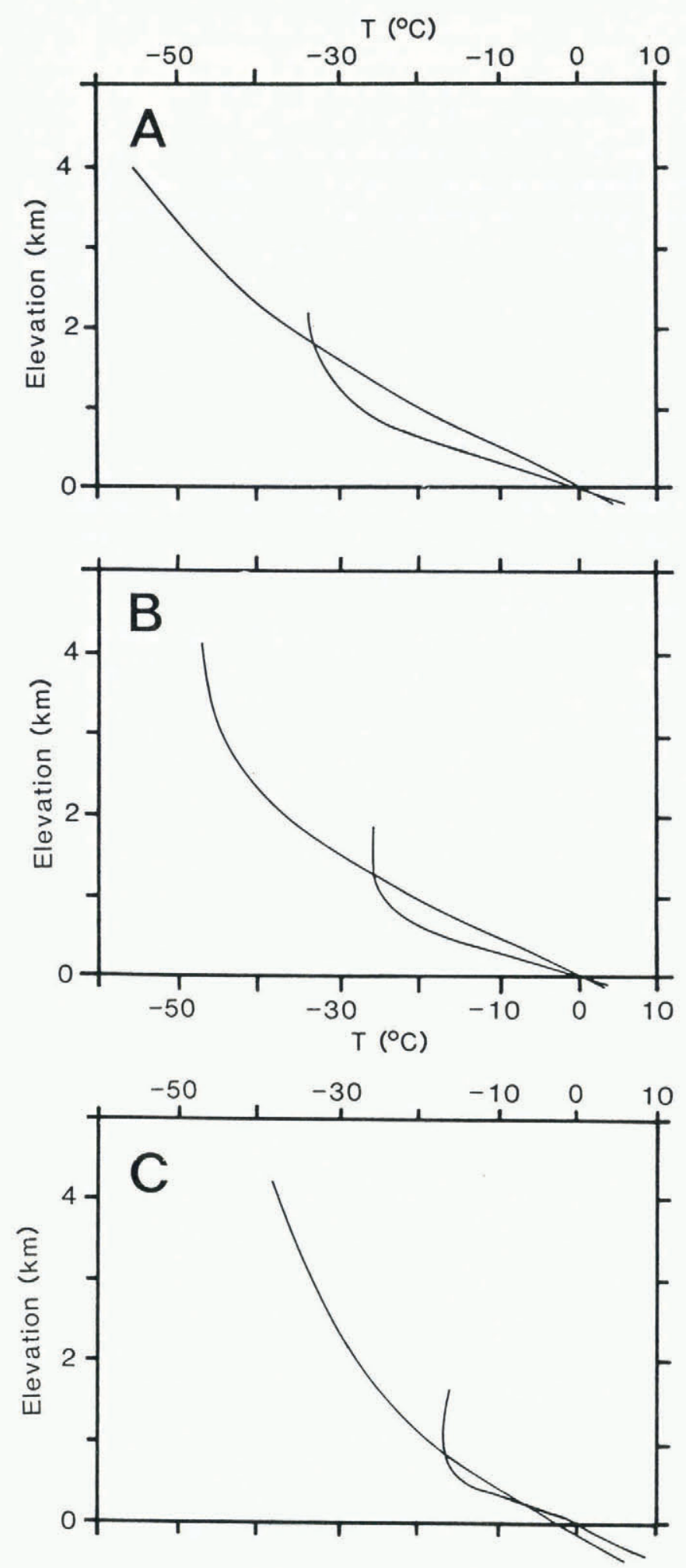

Fig. 7. Temperature-depth distribution for climates $A-C$ 500 and $1700 \mathrm{~km}$ outbound from the centre point of the ice sheet (model III).

\section{Allan Hills Icefield}

The surface and sub-ice topography, as well as the dynamics of the ice flow across the region to the west of Allan Hills, Victoria Land, have already been described in Delisle and Sievers (1991) and Schultz and others (1990). Figure 9 shows a cross-section from Allan Hills westwards along the existing triangulation network (Annexstad and Schultz, 1983). The westward-sloping blue icefield adjacent to Allan Hills flows at several $\mathrm{cm} \mathrm{a}^{-1}$ northwestwards, while being exposed to a sublimation rate of about $5 \mathrm{~cm} \mathrm{a}^{-1}$ (see Delisle and others, 1989). This icefield, currently not resupplied by advected ice, decays at this time and will, assuming an unchanged sublimation rate, have disappeared in about 5000 years. This blue icefield has obviously been formed in a recent period of a regionally higher ice stand with ice flow toward Allan Hills from the west. The above numerical model suggests that a higher ice stand most likely existed for the last time during the termination of the last glacial stage. This situation is the more intriguing as Allan Hills Icefield is distinguished by one of the major Antarctic meteorite concentrations. The increase in ice thickness cannot have exceeded the height of Allan Hills. Otherwise, ice flow would have transported away the currently exposed blue ice with entrapped meteorites with terrestrial ages of typically several hundred thousand years (Nishiizumi and others, 1989).

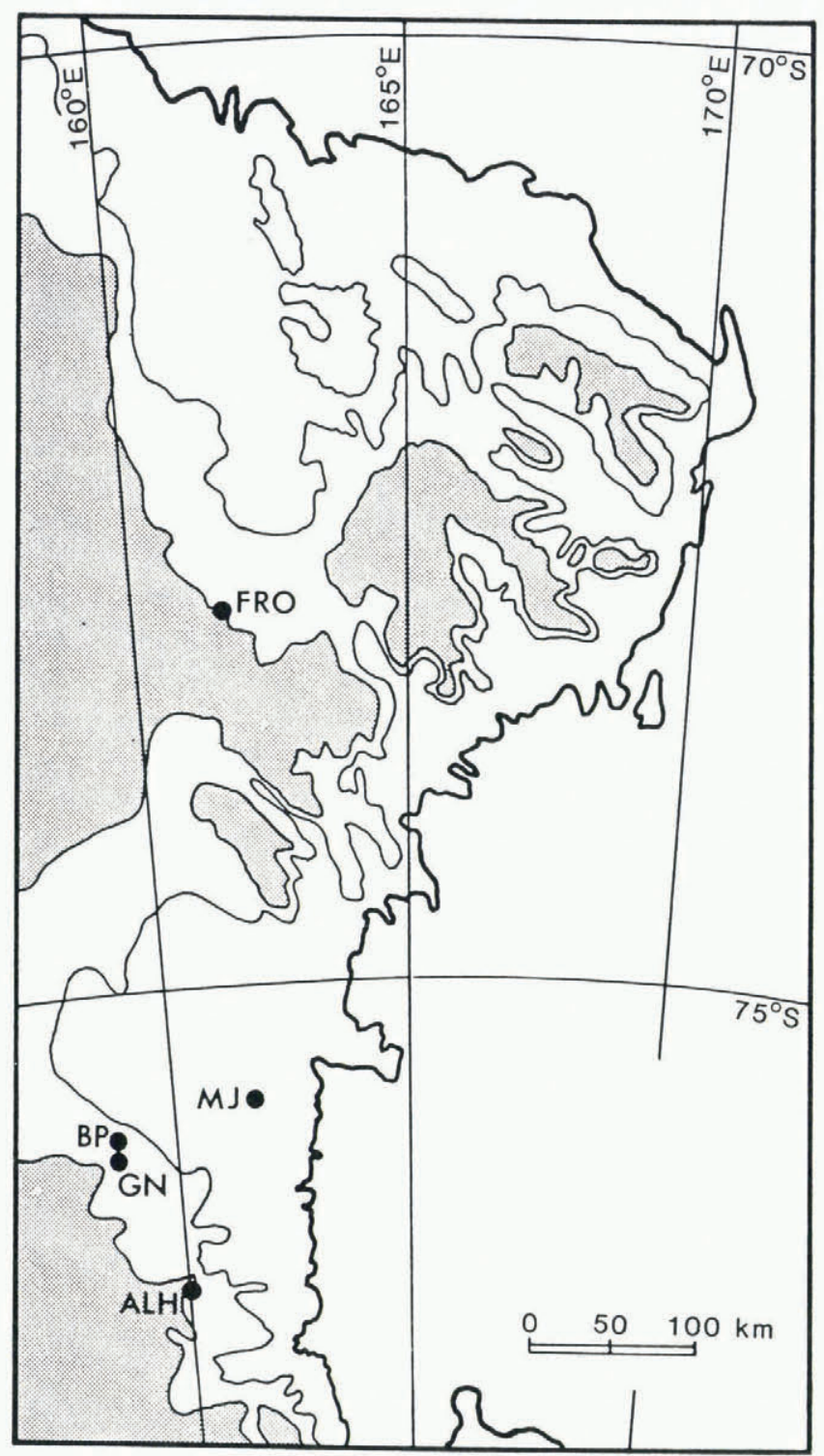

Fig. 8. Location of surveyed blue icefields in Victoria Land and north Victoria Land. Regions $2000 \mathrm{~m}$ above m.s.l. are shaded. $F R O=$ Frontier Mountain; $M \mathcal{F}=$ Mount Joyce; $B P=$ Brimstone Peak; $G \mathcal{N}=$ Griffin Nunatak; ALH $=$ Allan Hills. 


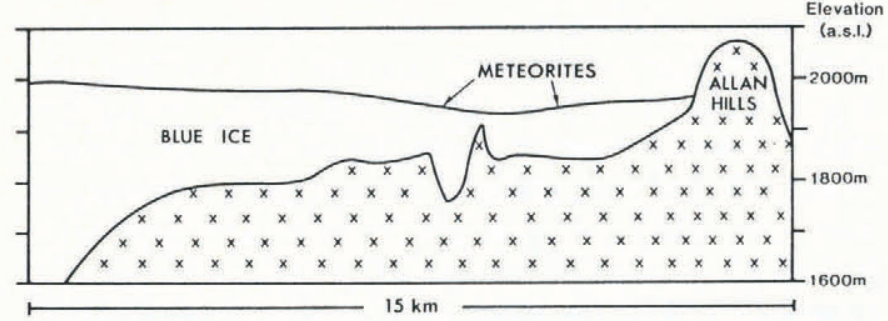

Fig. 9. Ice-surface and sub-ice topography along a profile from Allan Hills westwards. The blue icefield next to Allan Hills slopes and flows westwards and has no nearby source area. The ice was deposited during an apparently recent period with a higher ice stand.

\section{Griffin Nunatak - Brimstone Peak}

Surface slopes and the ice-thickness distribution of the icefield around these two nunataks were investigated in detail in 1991. On the leeside of both mountains, large blue icefields exist, on which ample evidence of a recently higher ice stand has been observed. Technical details on the radar instrumentation used to determine the sub-ice topography can be found in Delisle and Sievers (1991).

\section{Griffin Nunatak}

The blue icefield to the northeast of Griffin Nunatak is on average $825 \mathrm{~m}$ thick as measured by radar (Figs 10 and 11) and rests on an almost flat bottom. The surface slope across this icefield is on average $7 \mathrm{~m} \mathrm{~km}^{-1}$, which implies very slow ice flow. The ice near the northeast flanks of Griffin Nunatak is covered by a continuous layer of debris, protecting the underlying ice from the heat radiation from adjacent rock walls. Therefore, only few ice depressions (bergschrund) along the flanks of Griffin Nunatak have developed. Four moraine trains, which were formed as lateral moraines during the last ice advance over Griffin Nunatak, run across the blue icefield (Fig. 10). Two of the lateral moraines delineate today exactly the extension of the valleys, through which ice streams over-riding Griffin Nunatak would have had to flow. Horizontal flow of blue ice since that event was obviously insufficient to deform the orientation of these moraines. Many rock fragments lie across the blue-ice surface between the moraine trains, which probably were transported at the base of the former over-riding ice stream. All these observations point to a regionally higher ice stand in the last few thousand years.

The trend of the last over-riding event is almost perpendicular to the deep glacial valley that separates Griffin Nunatak from Brimstone Peak. In the distant past, a drastically different glaciological flow regime, oriented west-east, must have existed in the region.

\section{Brimstone Peak}

The surface and sub-ice topography of the blue ice to the east and north of Brimstone Peak are very complex (Figs 10 and 11). Near the flanks of Brimstone Peak, in particular at the north face, deep depressions in the ice surface and subsequent formation of meltwater lakes have developed. To the northeast of Brimstone Peak at distances $>2 \mathrm{~km}$, large areas of blue ice are covered with a thin rock veneer consisting of fist-size or larger fragments, which might be the remnants of a basal moraine of a former over-riding ice stream. About $2 \mathrm{~km}$ north of the northeast corner of Brimstone Peak, two moraines (shown in Figure 10 near the 1600 m contour), consisting on the southern end primarily of Beacon Sandstone with large inclusions of fossil wood and, on the northern end predominantly of Ferrar dolerite, are perched on top of $600 \mathrm{~m}$ of blue ice. A number of shear planes indicate shortening of the moraines along the long axis. The moraines rest in part on, and in part next to, a steep ice slope. The details of origin, path and extent of the previous over-riding ice stream that deposited the moraines are unclear.

The first outcrop to the north of Brimstone Peak, about $4 \mathrm{~m}$ above the current ice level, shows glacial striations indicating previous glacial flow from the westnorthwest. These striations incised in soft Beacon Sandstone presumably originated from the last episodic higher ice stand.

Large boulders of ice-transported Beacon Sandstone of fresh appearance rest about $300 \mathrm{~m}$ above the current level on the northern flank of Brimstone Peak, which itself is composed exclusively of a succession of basaltic flows of Jurassic age (the fine-grained equivalent to the Ferrar dolerite). Ice-cored scree slopes rise about $200 \mathrm{~m}$ high along the east face of Brimstone Peak. Both observations are again indicative of a higher ice level in the recent past.

The most unusual feature on this blue icefield is a system of metre-wide crevasses ( $1 \mathrm{~km}$ to the north of the northeast corner of Brimstone Peak; see also Figure 10), which cannot be explained by current ice-flow processes.

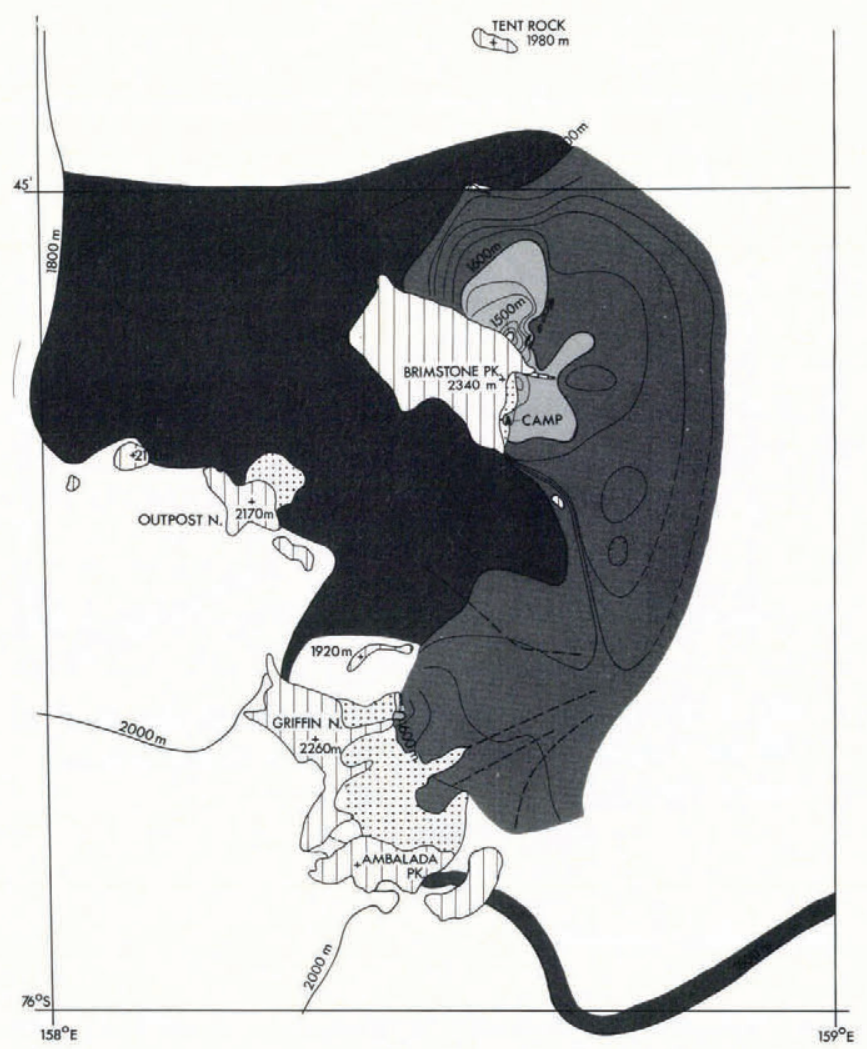

Fig. 10. Surface topography of the Griffin Nunatak and Brimstone Peak area. Located to the north of the northeast corner of Brimstone Peak is an inactive crevasse field (black area; see discussion in text) and two moraines (dotted area) resting on about $600 \mathrm{~m}$ of blue ice. 


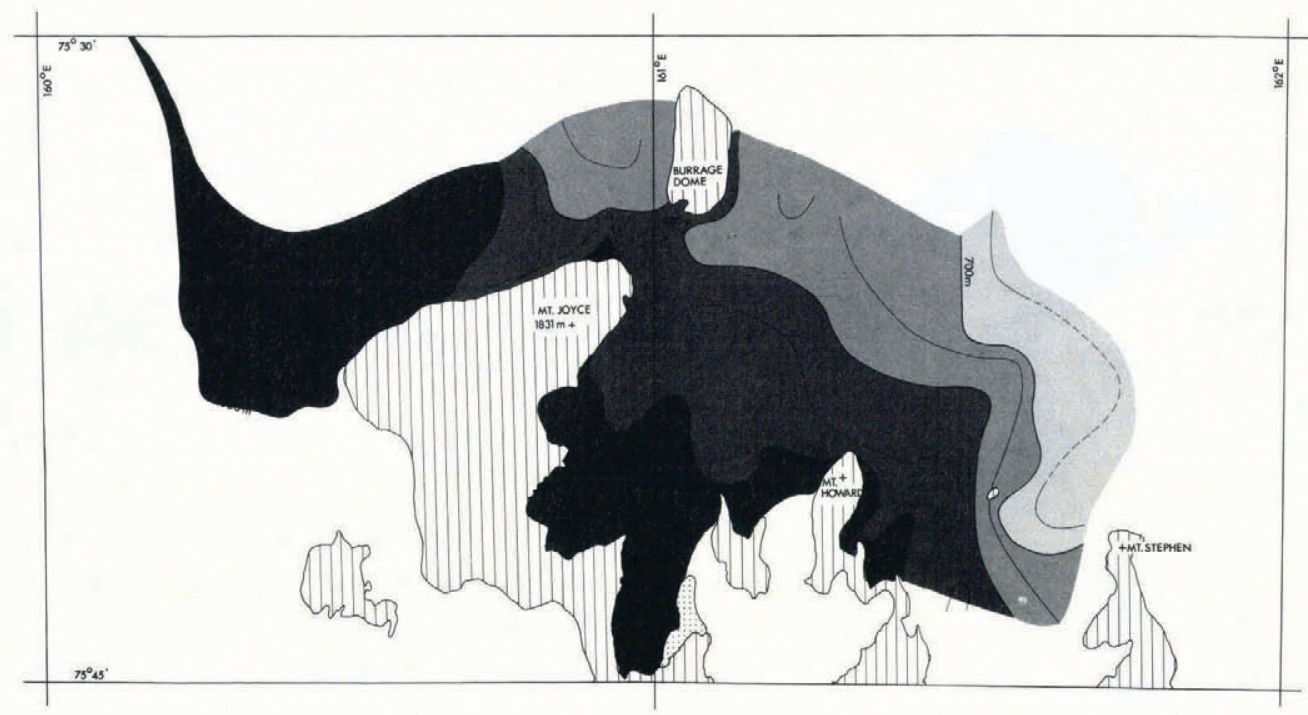

Fig. 13. Surface topography of the Mount Foyce area. Dashed lines (north of Mount Foyce) show prominent moraine trains deposited presumably during the last glacial stage.

situation. The ice surface at the valley entrance forms a depression, which is delineated by a band of large boulders (Fig. 16a).

The development of the surface topography in "Meteorite Valley" can be explained by an inversion of topography as depicted in Figure 16a-c. In the initial stage, a higher ice level prevailed. Local valley-glacier ice and blue ice from outside the valley (Fig. 16a) met at the valley entrance, where horizontal ice flow from both sides approached zero. Sublimation caused a shallow depression in the zone of slow ice flow, in which ice-transported rock material, primarily rocks and boulders from the surrounding rock walls and from the glacier beds, and meteorites entrapped in ice, gathered with time. The regional ice level was lowered, as the climate warmed up. A meltwater lake formed in the depression. The rock material and the meteorites became immersed (Fig. 16b) in water. Evidence to this effect is available through the exceptionally high uranium content of all meteorites from "Meteorite Valley". The concentration can be explained by prolonged leaching of uranium from local granitic rocks by meltwater and diffusion into the meteorites (for more details see Delisle and others (1989)). In the case of "Meteorite Valley", the meltwater lake has now receded far to the rear of the valley, while the former ice depression forms a topographic high, not nourished by ice flow from either side and protected against sublimation by the rock veneer on its surface (Fig. 16c).

Ice from the Polar Plateau forms a snow-and-ice cliff overlooking Frontier Mountain at the rear end of "Meteorite Valley" by about $50 \mathrm{~m}$ (see figure 3 in Delisle and others (1989)). However, the ice is apparently too cold to flow into the valley. A more than modest increase in ice thickness would cause the ice from the Polar Plateau to make its way through the valley northwards, thereby destroying the existing meteorite concentration.

\section{DISGUSSION}

The four models presented on ice-sheet development

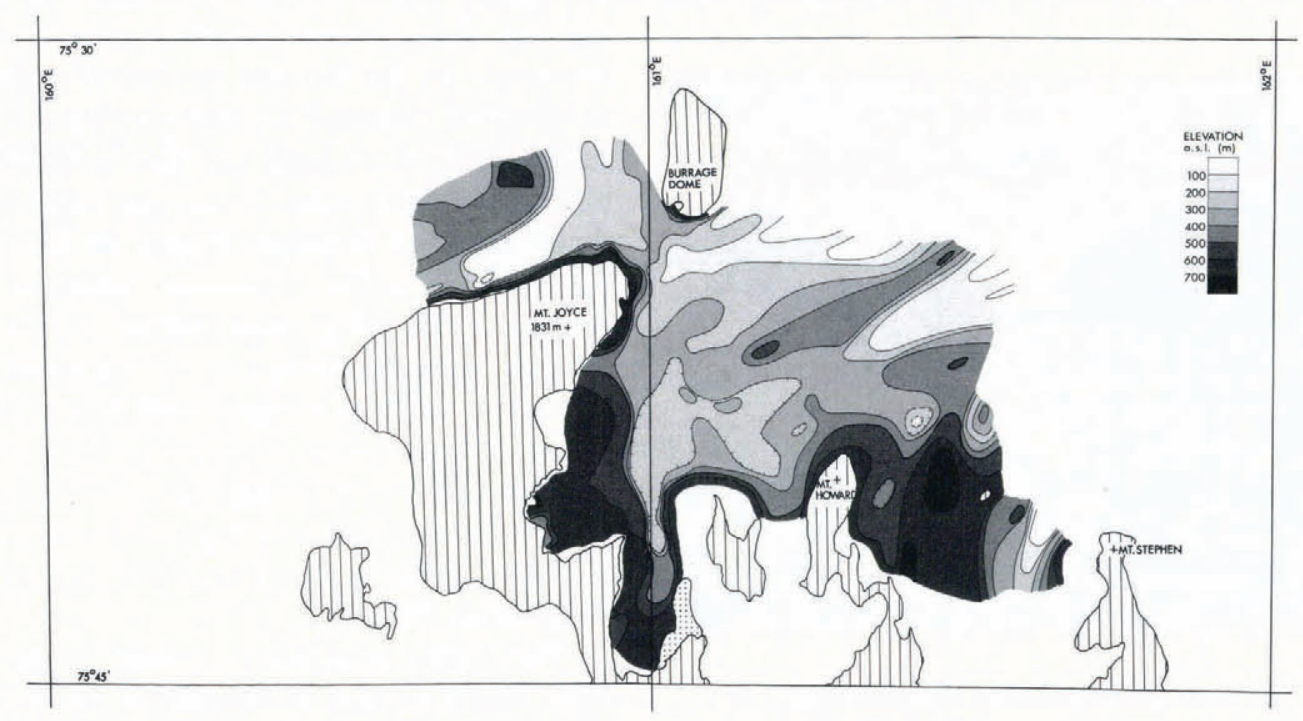

Fig. 14. Sub-ice topography of the Mount Foyce area. 


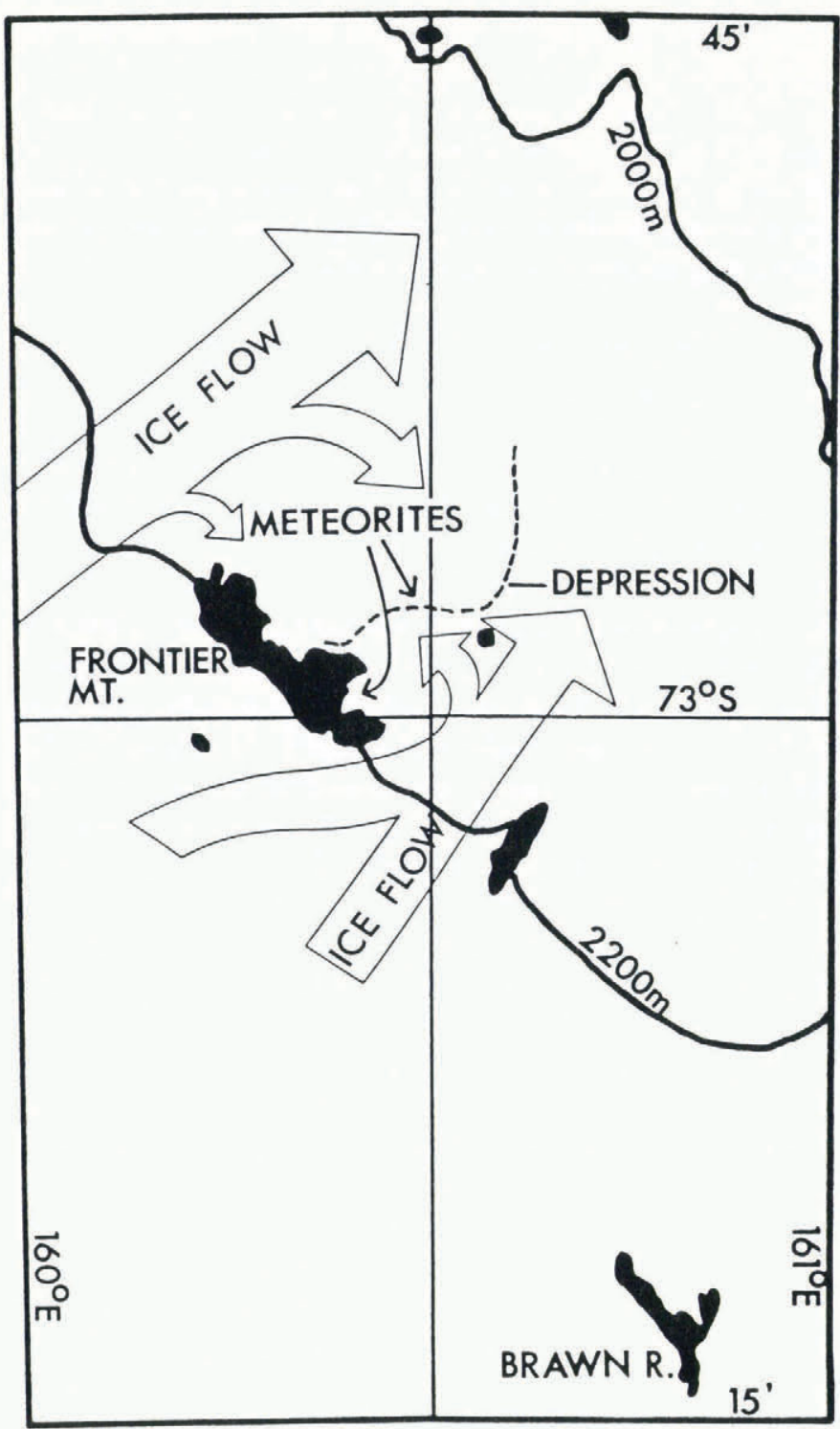

Fig. 15. Regional ice flow around Frontier Mountain. "Meteorite Valley" is located near the southeast end of the mountain.

under variable climatic conditions have produced compatible results, which are believed to indicate the trend and order of magnitude of changes that one might expect for an Antarctic ice sheet in response to climatic fluctuations since the late Tertiary. The available field evidence supports the numerical results as will be shown below.

The numerical model suggests a drastically different behaviour of the East Antarctic ice sheet during warmer climates of the late Tertiary. The ice thickness in the centre of East Antarctica should have surpassed the current values by several hundred metres. In near-coastal regions, in particular at sites also known for their meteorite occurrences today, $300-400 \mathrm{~m}$ thinner ice is predicted. The peripheral areas of the ice sheet were perennially warm-based and should have caused much more erosion at the bedrock than the present ice regime. Given the then existing wet-based conditions over large areas and the very high flow velocities, small-scale maybe even intermittently large-scale, surge events cannot be precluded.
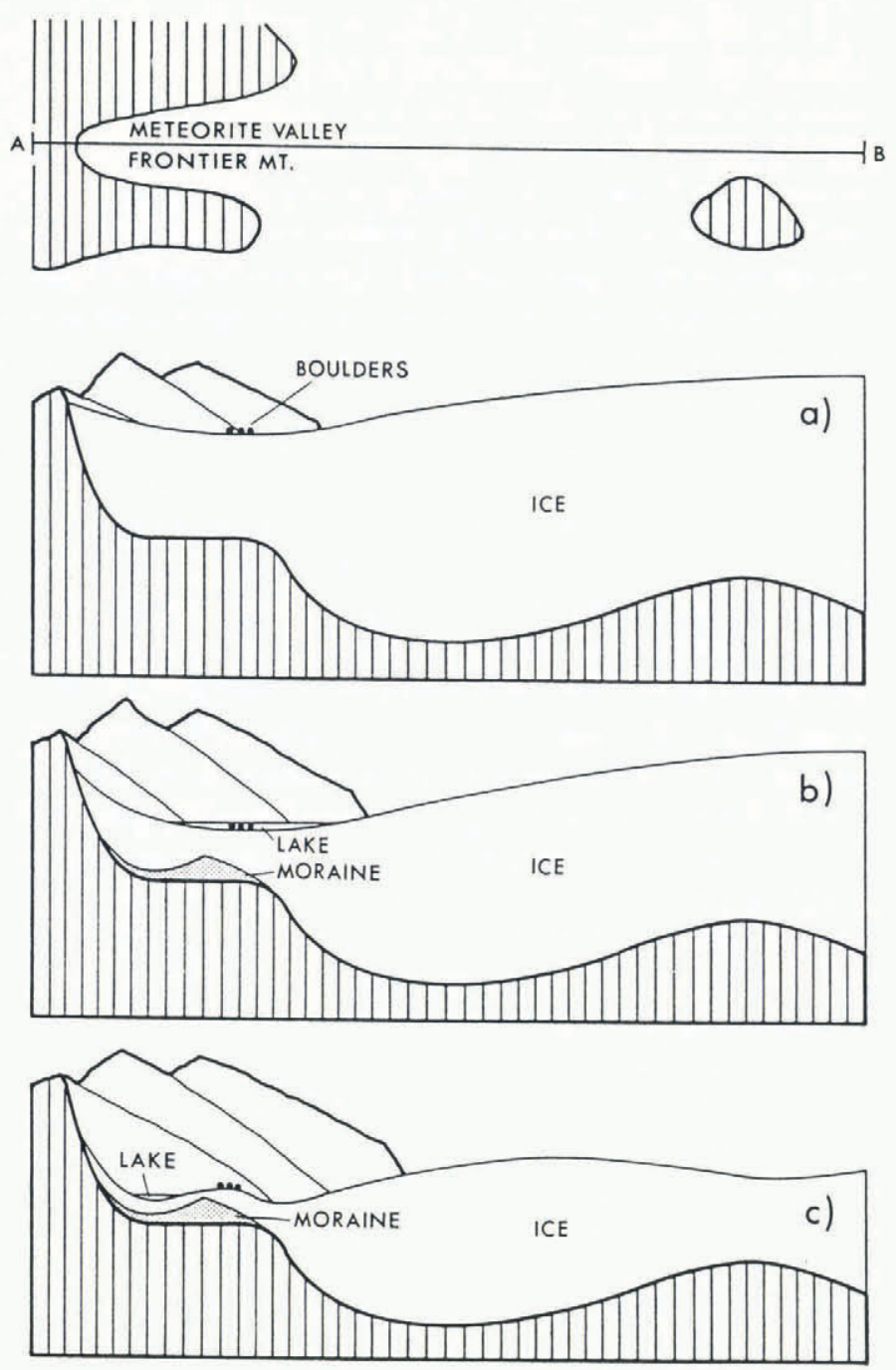

Fig. 16. The current field situation in "Meteorite Valley" (c) can best be explained by an inversion of topography induced by ice-level fluctuations due to the glaciall interglacial cycle. Glacial period $=(a)$, transitional period $=(b)$ and current interglacial stage $=(c)$. Meteorites are found in the boulder region on the ice ridge over the moraine.

Radar surveys across the Allan Hills and Griffin Nunatak Icefields clearly indicate a once drastically different ice-flow regime. Deeply eroding ice flow towards east to southeast was once predominant in the Griffin Nunatak area (Fig. 11). The sub-ice topography at Allan Hills and near Western Icefield was formed in part by local, alpine-type glaciers that flowed to the southwest-northwest towards the continent (figures 4 and 5 in Delisle and Sievers (1991))! This is compatible with the view of Webb (1991), Harwood (1991) and McKelvey and others (1991) of intermittent ice-free basins to the west of the Transantarctic Mountains during the early and late Pliocene, into which these glaciers could have drained. A more conservative view would be to assume a several hundred meters on average lower ice level during warmer Tertiary climates, as predicted by the above model.

Nishiizumi and others (1991) have measured the exposure and erosion history of the Allan Hills region on the basis of the cosmic-ray-produced ${ }^{10} \mathrm{Be}$ and ${ }^{26} \mathrm{Al}$ content in the surface rocks. ${ }^{10} \mathrm{Be}$ with a half-life of 
$1.5 \times 10^{6} \mathrm{a}$ and ${ }^{26} \mathrm{Al}\left(t_{\frac{1}{2}}=0.705 \times 10^{6} \mathrm{a}\right)$, have different cosmic-ray-induced production rates and offer independent measurements on the time of the surface exposure. The data by Nishiizumi and others suggest that "the Allan Hills have been exposed above the present ice surface for more than half a million years and that the erosion rate for these rocks is less than a few times $10^{-5} \mathrm{~cm}$ $\mathrm{a}^{-1}$." The oldest "minimum-exposure age" measured on a sample from an outcrop $15 \mathrm{~m}$ above the current ice level was $1.4( \pm 0.34) \times 10^{6}$ years. They found that the slightly different exposure ages obtained from the concentrations of the two isotopes suggest only intermittent and short-term burial of the rock surfaces by snow or ice since their first exposure. These results indicate either higher erosion rates during the early Pleistocene, producing fresh rock surfaces at a faster rate than today or, alternatively, require a persistent glacial cover of the area before the mid-Pleistocene. A glaciated terrain is required at least at some stage as a source area for the above-mentioned alpine type, westward-moving glaciers.

The above scenario does not preclude the possibility of major advances of a C-type ("Tertiary") polar ice sheet across coastal mountain ranges. An advance could, for example, have occurred at times of a worldwide drop in sea level, which would automatically cause the ice front to advance outwards across the continental shelf. An advance by only $100 \mathrm{~km}$ would raise the ice level by about $0.7-1.5 \mathrm{~km}$ (see Fig. 3c) in near-coastal areas of today. An advancing C-type glacier would be even more prone to surge and would probably partially decay within a matter of a few thousand years.

The available field record implies that both scenarios:

low ice level in the Transantarctic Mountains and local alpine-type glaciation and active erosion;

major glacial advances out into the Ross Sea and over the East Antarctic continental shelf, causing major unconformities in the marine sediments (see e.g. Hinz and Block, 1983; Hinz and Kristoffersen, 1987; Bartek and others, 1991),

have occurred during the late Tertiary.

For the case in which colder climates took over with the transition from the Tertiary to the Quaternary, the numerical model predicts the ice-flow regime near the Antarctic coasts to have been altered:

Warm-based thin glaciers were replaced in nearcoastal areas by cold-based thicker ice.

Erosion at the glacier bed was greatly reduced, the then existing sub-ice topography having been preserved ever since.

Ice flow did not follow local topography any more but moved across it in the general direction toward the catchment areas of the large outlet glaciers.

Today, cold-based ice flow with neglegible erosion capability prevails at Allan Hills (Delisle and Sievers, 1991), Griffin Nunatak and Brimstone Peak alike. Ice flow at the latter two locations is controled locally by sublimation and ablation processes along mountain flanks (Fig. 10).

Field evidence points to significant ice-level fluctuations in Holocene times at the edge of the Polar Plateau. To what extent is the formerly higher ice stand in the case of Allan Hills, Griffin Nunatak, Brimstone Peak and Mount Joyce attributable to:

(a) The response of the Polar ice sheet to climatic changes as proposed by the above model?

(b) The barrier effect of the then higher and more extensive Ross Ice Shelf on the outlet glaciers during the last glacial stage?

An elevation of the Ross Ice Shelf to the east of Mount Joyce of $400-500 \mathrm{~m}$ at the time of maximum advance during the late Wisconsin has been suggested (see e.g. figure 12 in Denton and others (1991)). It seems that the latest increase in ice thickness around Mount Joyce has to be attributed to (a) and (b) alike. The episodic increase in ice thickness around Allan Hills, Griffin Nunatak and Brimstone Peak 70-115 km to the west of the coast, and in addition separated from the Ross Sea by the Transantarctic Mountains chain, is more easily explained by effect (a).

Frontier Mountain is located at the upper end of the Rennick Glacier drainage system that empties into the South Pacific Ocean. Mayewski and others (1979) have recognized two major glacial episodes, termed the Evans and the younger Rennick Glaciations. Both are connected with an advance of the grounding line of Rennick Glacier northwards and an increase in height of the ice surface to the south. The timing of both events is uncertain. They believe the ice had thickened during the Rennick Glaciation by about $300 \mathrm{~m}$ in the wider vicinity of Frontier Mountain. The local meteorite traps would not have survived such an event (see above). The Rennick Glaciation either caused a smaller rise in the ice surface in this area or it is older than the meteorite traps.

The numerical models suggest that the known Antarctic meteorite traps are permanently maintained and are supplied by continental ice only, ever since the climatic deterioration during the Pleistocene. Meteorites that have fallen on to the Polar Plateau are transported to meteorite traps on the order of $10^{5}$ years or less. No Antarctic meteorite with a terrestrial age of more than $1 \mathrm{Ma}$ has been found on blue ice, despite the fact that their weathering degree does not strongly correlate with their terrestrial age (see e.g. Nishiizumi and others, 1989). It therefore seems that this age limit indicates a maximum age of current Antarctic meteorite traps.

How was the effectiveness of various meteorite traps affected by changing ice stands? In the case of Frontier Mountain, moderate changes do not affect the principal mode of meteorite concentration, only the speed by which ice moves toward the meteorite trap. The case of Allan Hills is more complicated. Colder and stiffer ice will reduce ice flow during glacials, and this should increase the ice thickness and reduce the regional surface slope (see Fig. 3a). Sublimation rates should be lower in the colder climate of glacial stages in comparison with today. Field evidence points to a locally greater ice thickness sometime 
ago (last glacial?) by no more than about $100 \mathrm{~m}$ (see also Fig. 9). Otherwise, the ice with the meteorites above it would have drained across Allan Hills into the next valley to the east, Manhaul Bay.

The postulated moderate decrease of ice thickness in near-coastal areas during interglacial stages provides a new mechanism for the formation of blue icefields. The surface of the ice and firn cover of rock plateaux comes potentially to level or rises above the elevation of the regional ice sheet in interglacial stages. Ice in deeply incised glacial valleys or ice streams can readily adjust to a new situation due to its high mobility. Thin ice on rock plateaux is almost immobile, as it stands above the regional level and becomes exposed to sublimation. A blue icefield develops. A case in point is the Allan Hills main icefield. It slopes down toward the east, north and northwest toward the regional ice streams. Today, it is only marginally supplied by new ice from the southwest. Most blue icefields disappear during glacial stages according to this theory.

If this scenario were true, there would be implications as to the mode of the storage of meteorites on blue ice during cold stages. Quite likely, they are then covered by a thin veneer of firn and snow, which would explain the often surprisingly low degree of weathering of the meteorites.

\section{CONCLUSIONS}

Numerical modeling of ice sheets and field evidence both point to a very different glacial regime prior to the climatic deterioration during the Pleistocene. It was characterized by fast-moving, wet-based and efficiently eroding ice in near-coastal areas of East Antarctica. Both scenarios,

short-term major advances out on to the continental shelf areas associated with over-riding of mountain tops, now raised well above the current ice level, and

long-term glaciation characterized by overall thinner ice in coastal areas, alpine-type glaciation in the Transantarctic Mountains and thicker ice in central parts of East Antarctica,

appear to be characteristic of late Tertiary times.

The glacial regime along the western boundary of the Transantarctic Mountains changed apparently with the climatic deterioration during the Pleistocene. The transition was characterized by an overall thickening of ice in near-coastal regions on the order of $\leqslant 500 \mathrm{~m}$.

Meteorite traps along the Transantarctic Mountains were formed after this transition. All of them exist near the $2000 \mathrm{~m}$ elevation contour in areas that, probably since the transition, had been permanently overflowed by continental ice. Blue icefields acting as meteorite traps today are exposed to ice thinning by moderate amounts in response to the current interglacial stage.

The ice thickness in near-coastal areas of Antarctica during an interglacial stage should in general decrease by $\leqslant 200 \mathrm{~m}$ in comparison to the previous glacial stage. This signal is difficult to separate from the amplitude of ice- surface lowering caused in the wider vicinity of a retreating shelf ice.

Blue icefields develop over rock plateaux and are best developed during interglacial stages. Advancing ice overflows some of them during glacial stages. Later blue icefields are unlikely to have high meteorite concentrations on their surfaces.

The occurrence of a re-frozen and highly deformed meltwater lake at the north face of Brimstone Peak might indicate a hypsithermal event in Victoria Land, possibly 4-7 ka ago.

\section{REFERENCES}

Annexstad, J. O. and L. Schultz. 1983. Measurements of the triangulation network at the Allan Hills meteorite icefield. In Oliver, R. L., P. R. James and J. B. Jago, eds. Antarctic earth science. Cambridge, etc., Cambridge University Press, 617-619.

Bartek, L. R., P.R. Vail, J. B. Anderson, P. A. Emmet and S. Wu. 1991. Effect of Cenozoic ice sheet fluctuations in Antarctica on the stratigraphic signature of the Neogene. 7. Geophys. Res., 96(B4), 67536778.

Behrendt, J. C. and A. Cooper. 1991. Evidence of rapid Cenozoic uplift of the shoulder escarpment of the Cenozoic West Antarctic rift system and a speculation on possible climate forcing. Geology, 19, 315-319.

Bremer, K. and 6 others. 1991. ${ }^{10}$ Be-content of quartz grains taken in north Victoria Land and the glacial history of the Frontier Mountains in Antarctica. Meteoritics, 26(4).

Budd, W. F. and N. W. Young. 1983. Techniques for the analysis of temperature-depth profiles in ice sheets. In Robin, G. de Q., ed. The climatic record in polar ice sheets. Cambridge, etc., Cambridge University Press, 145150.

Budd, W. F., D. Jenssen and I. N. Smith. 1984. A threedimensional time-dependent model of the West Antarctic ice sheet. Ann. Glaciol., 5, 29-36.

Cassidy, W. A., R. Harvey, J. Schutt, G. Delisle and K. Yanai. 1992. The meteorite collection sites of Antarctica. Meteoritics, 27(5), 490-525.

Delisle, G. 1991. Causes and consequences of the advance of a continental ice sheet from Scandinavia to northern Germany. Geol. Jahrb., Reihe A, 127, 507-517.

Delisle, G. and J. Sievers. 1991. Subice topography and meteorite finds near the Allan Hills and the near Western Icefield, Victoria Land, Antarctica. 7 . Geophys. Res., 96(E1), 15,577-15,587.

Delisle, G. and 11 others. 1989a. Meteorite finds near the Frontier Mountain range in north Victoria Land. Geol. Jahrb., Reihe E, 38, 483-513.

Delisle, G., J. Sievers and L. Schultz. 1989b. Radio-echo sounding survey across the Allan Hills Icefield. Antarct. J. U.S., 24(5), 50-52.

Denton, G. H. and T.J. Hughes. 1981. The last great ice sheets. New York, etc., John Wiley and Sons.

Denton, G. H., M. L. Prentice, D. E. Kellogg and T.B. Kellogg. 1984. Late Tertiary history of the Antarctic ice sheet: evidence from the dry valleys. Geology, 12(5), 263-267. 
Denton, G.H., J. G. Bockheim, S. C. Wilson and M. Stuiver. 1991. Late Wisconsin and Early Holocene glacial history, inner Ross Embayment, Antarctica. In Bindschadler, R. A., ed. West Antarctic Ice Sheet Initiative. Volume 2: discipline reviews. Washington, DC, National Aeronautics and Space Administration, 55-86. (NASA Conference Publication 3115.)

Domack, E.W., A.J.T. Jull and S. Nakao. 1991. Advance of East Antarctic outlet glaciers during the hypsithermal: implications for the volume state of the Antarctic ice sheet under global warming. Geology, 19(11), 1059-1062.

Haq, B. U., J. Hardenbol and P. R. Vail. 1987. The chronology of fluctuating sea level since the Triassic. Science, 235, 1156-1167.

Harwood, D. M. 1983. Diatoms from the Sirius Formation, Transantarctic Mountains. Antarct. F. U.S., 18(5), 98-100.

Harwood, D. M. 1991. Cenozoic diatom biogeography in the southern high latitudes: inferred biogeographic barriers and progressive endemism. In Thomson, M. R.A., J.A. Crame and J.W. Thomson, eds. Geological evolution of Antarctica. Cambridge, etc., Cambridge University Press, 667-673.

Herterich, K. 1988. A three-dimensional model of the Antarctic ice sheet. Ann. Glaciol., 11, 32-35.

Hinz, K. and M. Block. 1983. Results of geophysical investigations in the Weddell Sea and in the Ross Sea, Antarctica. In Proceedings of the 11th World Petrological Congress (London). New York, John Wiley, 79-91.

Hinz, K. and Y. Kristoffersen. 1987. Antarctica - recent advances in the understanding of the continental shelf. Geol. Jahrb., Reihe E, 37, 1-54.

Höfle, H.-C. 1987. Glacial geology in the Outback Nunataks area, west of northern Victoria Land, Antarctica. In Meer, J.J.M. van der, ed. Tills and glaciotectonics. Rotterdam and Boston, Balkema, 253257.

Höfle, H. C., G. Delisle, U. Herpers, K. Bremer, H.J. Hofmann and W. Wölfli. 1992. Further evidence for a glacial maximum in Antarctica during the Upper Neogene. Z. Geomorphol., N.F., Supplement-Band 86, 121-133.

Huybrechts, P. and J. Oerlemans. 1988. Evolution of the East Antarctic ice sheet: a numerical study of thermomechanical response patterns with changing climate. Ann. Glaciol., 11, 52-59.
Lorius, C., N. I. Barkov, J. Jouzel, Y.S. Korotkevich, V. M. Kotlyakov and D. Raynaud. 1988. Antarctic ice core: $\mathrm{CO}_{2}$ and climatic change over the last climatic cycle. EOS, 69(26), 681-685.

McKelvey, B.C., P.N. Webb, D. M. Harwood and M. C. G. Mabin. 1991. The Dominion Range Sirius Group: a record of the late Pliocene-early Pleistocene Beardmore Glacier. In Thomson, M. R.A., J.A. Crame and J. W. Thomson, eds. Geological evolution of Antarctica. Cambridge, etc., Cambridge University Press, 675-682.

Mayewski, P. A., J. W. Attig, Jr and D.J. Drewry. 1979. Pattern of ice surface lowering for Rennick Glacier, northern Victoria Land, Antarctica. 7. Glaciol., 22(86), 53-65.

Miller, K. G., R. G. Fairbanks and G. S. Mountain. 1987. Tertiary oxygen isotope synthesis, sea level history, and continental margin erosion. Paleoceanography, 2(1), 119.

Nishiizumi, K., D. Elmore and P.W. Kubik. 1989. Update on terrestrial ages of Antarctic meteorites. Earth Planet. Sci. Lett., 93(3-4), 299-313.

Nishiizumi, K., C.P. Kohl, J. R. Arnold, J. Klein, D. Fink and R. Middleton. 1991. Cosmic ray produced ${ }^{10} \mathrm{Be}$ and ${ }^{26} \mathrm{Al}$ in Antarctic rocks: exposure and erosion history. Earth Planet. Sci. Lett., 104, 440-454.

Nye, J.F. 1959. The motion of ice sheets and glaciers. $\mathcal{f}$. Glaciol., 3(26), 493-507.

Oerlemans, J. 1982. A model of the Antarctic ice sheet. Nature, 297(5867), 550-553.

Peltier, W. R. and A. M. Tushingham. 1991. Influence of glacial isostatic adjustment on tide gauge measurements of secular sea level change. $\mathcal{F}$. Geophys. Res., 96(B4), 6779-6796.

Schultz, L., J. O. Annexstad and G. Delisle. 1990. Ice movement and mass balance at the Allan Hills Icefield. Antarct. F. U.S., 25(5), 94-95.

Webb, P. N. 1991. A review of the Cenozoic stratigraphy and palaeontology of Antarctica. In Thomson, M. R.A., J.A. Crame and J.W. Thomson, eds. Geological evolution of Antarctica. Cambridge, etc., Cambridge University Press, 599-607.

The accuracy of references in the text and in this list is the responsibility of the author, to whom queries should be addressed. 